Document downloaded from:

http://hdl.handle.net/10251/141977

This paper must be cited as:

Almeida De-Godoy, V.; Zuquette, L.; Gómez-Hernández, JJ. (09-2). Scale effect on hydraulic conductivity and solute transport: Small and large-scale laboratory experiments and field experiments. Engineering Geology. 243:196-205.

https://doi.org/10.1016/j.enggeo.2018.06.020

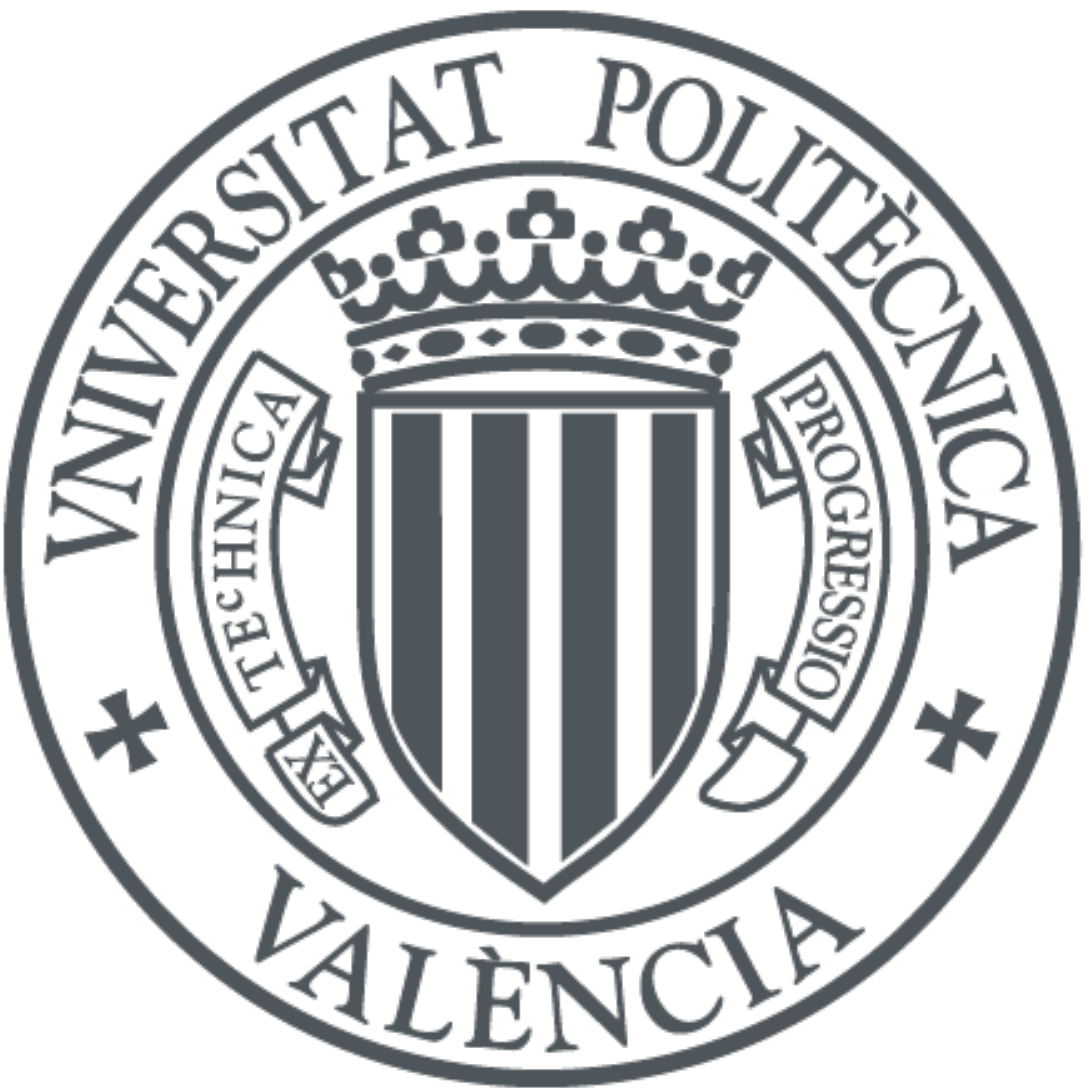

The final publication is available at

https://doi.org/10.1016/j.enggeo.2018.06.020

Copyright Elsevier

Additional Information 
Vanessa A. Godoy ${ }^{1,2^{*}}$, Lázaro Valentin Zuquette $^{1}$ and J. Jaime Gómez-Hernández ${ }^{2}$

${ }^{1}$ Geotechnical Engineering Department, São Carlos School of Engineering, University of São Paulo. Avenida Trabalhador São Carlense, 400, 16564-002, São Carlos, São Paulo, Brazil.

${ }^{2}$ Institute for Water and Environmental Engineering, Universitat Politècnica de València, Camí de Vera, s/n, 46022, València, Spain

“corresponding author: valmeida@usp.br (+55)16 35739501

\title{
Scale effect on hydraulic conductivity and solute transport: small and large-scale laboratory experiments and field experiments
}

\section{Highlights}

- Hydraulic conductivity increases with scale for the same measurement condition.

- Dispersivity increases with sample height following exponential functions.

- Partition coefficient increases with sample support following linear functions.

- The scale effect obtained can be explained by the soil heterogeneities.

- To improve predictions reliability and accuracy, scale effect should be considered.

\begin{abstract}
Hydraulic conductivity $(K)$, dispersivity $(\alpha)$ and partition coefficient $\left(K_{d}\right)$ can change according to the measurement support (scale) and that is referred as scale effect. However, there is no clear consensus about the scale behavior of these parameters. Comparison between results obtained in different support of measurements in the field and in the laboratory can promote the discussion about scale effects on $\mathrm{K}, \alpha$ and $\mathrm{K}_{\mathrm{d}}$, and contribute to understanding how these parameters behave with the change in the scale of measurement, the main objectives of the present paper. Small and large-scale laboratory tests using undisturbed soil samples and field experiments at different scales were performed. Results show that for the same measurement condition $K, \alpha$ and $K_{d}$ increase with scale, in all studied magnitudes. Caution should be taken when using $K, \alpha$ and $K_{d}$ values in numerical models with no concern about the scale effect. The lack of consideration of the difference of scale between field and laboratory measurements and numerical model may compromise the reliability of the predictions and misrepresent the responses.
\end{abstract}

Keywords: undisturbed soil sample, column experiment, double-ring infiltrometer, infiltration ditch, tropical soil 


\section{Introduction}

Numerical models are tools used in the geotechnical and geoenvironmental practice to solve a wide range of problems related to water flow and solute movement in the subsurface (Dou et al., 2014; Ghiglieri et al., 2016; Navarro et al., 2017; Wang et al., 2017). Hydraulic conductivity (K) and the solute transport parameters such as hydrodynamic dispersion coefficient (D), dispersivity $(\alpha)$, partition coefficient $\left(K_{d}\right)$, and retardation factor $(R)$ are key input parameters for these numerical models and their proper determination is fundamental (Bouchelaghem and Jozja, 2009).

In common practice, these parameters are determined in the field or in the laboratory, and then they are used in models to conduct predictions, with no concern about the scale (support) at which they were measured (Godoy et al., 2015; Latorre et al., 2015; Liu et al., 2014). But the value of these parameters can change according to the measurement support, and when that change is not considered, the reliability of the predictions may be compromised (Godoy et al., 2018; Sánchez-Vila et al., 1996). The dependence of parameter values on measurement support is called scale effect, it is a result of the parameters spatial variability (Sánchez-Vila et al., 1996), and it has been the subject of many studies (Salamon et al., 2007; Yang et al., 2017).

In the last decades, scale effects on mechanical properties relevant to geotechnical problems have been studied (Bahaaddini et al., 2014; Yilmaz et al., 2015; Yoshinaka et al., 2008). However, experimental studies of scale effects on $\mathrm{K}$ and solute transport parameters have received less attention. Most experimental studies of scale effects in solute transport are related to $\alpha$ and have shown that it increases with the scale (Domenico and Robbins, 1984; Gelhar and Axness, 1983; Vik et al., 2013). Regarding K, some authors suggested that there is no scale effect and that the differences in value at different scales are primarily due to problems during the measurements and not due to its measurement support (Butler and Healey, 1998a, 1998b). However, many studies have shown that $\mathrm{K}$ computed in the laboratory tend to have a smaller mean and a larger variance than $\mathrm{K}$ observed in the field over larger scales (Chapuis et al., 2005; Clauser, 1992; Sobieraj et al., 2004; Yang et al., 2017). In any case, scale effects may vary according to measurements conditions, geological characteristics and the spatial correlation length of $\mathrm{K}$ in a specific site (Neuman, 1994; Tidwell, 2006).

Undisturbed soil cores of a range of sizes have been used to evaluate the scale effects on D and $\alpha$ (Khan and Jury, 1990; Parker and Albrecht, 1987). The scale effects on sorption parameters such as $R$ and $K_{d}$ were studied numerically by some authors (Cassiraga et al., 2005; Gómez- 
Hernández et al., 2006), however, experimental studies are rare, mainly due to the difficulty in conducting large-scale reactive solute transport experiments. Most of the investigations in scale effects on $\mathrm{K}$ compare small-scale laboratory tests (i.e., permeameter tests) with intermediatescale aquifer tests (i.e., slug tests), and with large-scale tests (i.e., pumping tests). In the geotechnical and geoenvironmental practice the tests used to determine soil saturated $\mathrm{K}$, such as column experiment, double-ring infiltrometer and falling-head infiltration ditch, are rarely used to analyze scale effects (Duong et al., 2013; Lai and Ren, 2007), resulting in a lack of knowledge that we hope to contribute to reduce.

It is noticeable that there is no clear consensus as to the scale effect on water flow and solute transport parameters. The main purpose of the present paper is to contribute to the discussion about scale effects on $\mathrm{K}, \alpha$, and $\mathrm{K}_{\mathrm{d}}$ and understanding how these parameters behave with the change in the scale of measurement. For this, we characterized a study area and performed small- and large-scale laboratory tests using undisturbed soil samples, and field experiments, at different scales. The studied geologic material is a tropical soil that is widely found across the São Paulo State in Brazil, and that was not been characterized yet in terms of scale effects on $\mathrm{K}, \alpha$, and $K_{d}$.

\section{Materials and methods}

\subsection{Basic description of the studied soil}

Field studies were carried out in the city of São Carlos (21 $51^{\prime} 38^{\prime \prime} \mathrm{S}, 47^{\circ} 54^{\prime} 14^{\prime \prime}$ W), located in the East-Center of the São Paulo State, Brazil. Based on granulometric analyses with and without deflocculant, depending on the flocculation of the soil's grains, the soil is classified as CL or SF, according to the Unified Soil Classification System (USCS). The geologic material studied comprises Cenozoic sediments that cover the Botucatu Formation (Paraná Sedimentary Basin, São Bento Group), constituted by unconsolidated sands with a thickness ranging from $5 \mathrm{~m}$ to 7 $\mathrm{m}$ and pebbles at the base, and are widely spread across São Paulo State (Giacheti et al., 1993). Tropical conditions and wheatering make the soil from the Cenozoic sediments highly lateritized (Giacheti et al., 1993). The main constituents of this soil are quartz, oxides, and hydroxides of aluminum, kaolinite, and gibbsite. Macropores and dual-porosity are also characteristics of this soil (Rohm, 1992). 


\subsection{Soil sampling and characterization}

Large- and small-scale undisturbed soil samples were taken from the bottom and slopes of excavated ditches by carefully introducing rigid polyvinyl chloride (PVC) cylinders into the soil. Small-scale samples were extracted in 23 locations in the $x-y$ plane in an area of $12 \mathrm{~m}$ along the $\mathrm{x}$-direction and $7 \mathrm{~m}$ along the $\mathrm{y}$-direction. For each $\mathrm{x}-\mathrm{y}$ coordinate, three samples were taken at three different depths: $0.5 \mathrm{~m}, 1.0 \mathrm{~m}$, and $1.5 \mathrm{~m}$ resulting in a dense sampling design. A total of 14 small-scale samples were discarded because they presented defects or cracks. Large-scale samples were taken in an area next to where the small-scale samples were taken, retaining only those without defects. Table 1 shows the dimensions and number of undisturbed samples taken.

Disturbed soil samples were collected to perform routine physical, physico-chemical, chemical and mineralogical characterization. Three replicates were used to determine the following parameters by using disturbed soil samples: $\mathrm{pH}$ in $\mathrm{H}_{2} \mathrm{O}, \mathrm{pH}$ in $\mathrm{KCl}, \Delta \mathrm{pH}\left(\mathrm{pH}_{\mathrm{KCl}}-\mathrm{pH}_{\mathrm{H} 2 \mathrm{O}}\right)($ Mekaru and Uehara, 1972), point of zero charge (PZC) $\left(2 \mathrm{pH}_{\mathrm{KCl}}-\mathrm{pH}_{\mathrm{H} 2 \mathrm{O}}\right)$ (Keng and Uehara, 1973), organic matter (ASTM, 2014a), and mineralogical composition by X-ray diffraction (Azaroff and Buerger, 1953).

Next, we describe the analyses performed for each of the small- and large-scale undisturbed soil samples. At the laboratory, dry density was determined as $\rho_{d}=M d / V t$, where $V t$ is the total volume of the soil sample (internal volume of each PVC cylinder) and Md is the dry mass of the soil sample (Knappett and Craig, 2012). Total porosity was calculated as $n=1-\rho_{d} / \rho_{s}$, where $\rho_{s}$ is the particle density, determined using the ASTM D 854-14 (ASTM, 2014b) as $2.71 \mathrm{Mg} \cdot \mathrm{m}^{-3}$ (Knappett and Craig, 2012). Mercury intrusion porosimetry (MIP) (Washburn, 1921) was performed and used to determine macroporosity (Ma), mesoporosity (Me), and microporosity (Mi) according to the classification proposed by Koorevaar et al. (1983), in which the diameters of Mi, Me, and Ma are $<30 \mu \mathrm{m}, 30-100 \mu \mathrm{m}$ and $>100 \mu \mathrm{m}$, respectively. Disturbed samples were taken from each one of the undisturbed samples and were air-dried and sieved through a \#10 mesh sieve (2 mm openings). Particle size distributions were determined according to ASTM D7928-17 (ASTM, 2017a) and ASTM D6913 / D6913M-17 (ASTM, 2017b). The methylene blue adsorption test using the filter paper method described by Pejon (1992) was used to determine the cation exchange capacity (CEC).

\subsection{Large- and small-scale column experiments}

The characteristics of the flow and transport laboratory experiments were the same for both small and large-scale experiments to allow the comparison between them. We used the PVC 
cylinders filled with undisturbed soil samples as rigid-wall permeameters and small- and largescale column experiments were conducted as follows. First, the soil samples were slowly saturated from the bottom with deionized water to remove possible entrapped air. And second, after column saturation, flow was reversed (now from top to bottom) and a column test was performed under a constant hydraulic gradient of 1 ; the flow rate $(Q)$ was measured. We took two measures per day for two weeks and we assumed that steady-state flow was achieved when $Q$ variations were below $5 \%$ in four consecutive measurements. Once steady-state was reached, we determined saturated hydraulic conductivity, K, specific discharge, $q$, and average linear velocity, $v$ (q/ne) (Freeze and Cherry, 1979), where ne is the effective porosity, which was calculated as the total porosity minus the porosity that corresponds to the soil water content at 33 $\mathrm{kPa}$ (suction equivalent to the soil field capacity) (Ahuja et al., 1984). After that, deionized water was substituted by a solution $2.56 \mathrm{~mol} \mathrm{~m}^{-3} \mathrm{KCl}$ composed by $100 \mathrm{mg} \mathrm{L}^{-1} \mathrm{~K}^{+}$and $90.7 \mathrm{mg} \mathrm{L}^{-1} \mathrm{Cl}^{-}$, referred to, later on, as the initial concentration, $\mathrm{C}_{0}$. Solute displacement tests were carried out under constant hydraulic head and isothermal $\left(20{ }^{\circ} \mathrm{C}\right)$ conditions. Leachate samples were collected from the outlet of the columns and concentrations (C) were measured at preset time intervals. An ion-selective electrode (ISE) (Hanna instruments - HI 4107 model) was used to determine the $\mathrm{Cl}^{-}$concentration. We used a flame photometer (Micronal B462 model) to measure the $\mathrm{K}^{+}$concentration at a 1:21 dilution ratio. The concentrations of the ions were measured two times for each sample and the arithmetic mean of the measures was used as the final value.

The breakthrough curves (BTC's) were given as $\mathrm{C} / \mathrm{C}_{0}$ vs. the number of pore volumes (T) injected. $T$ is a dimensionless variable calculated as $T=v t / L$ (van Genuchten, 1980), where $v$ is the average linear velocity, $t$ is the time elapsed from the start of the solute application, and $L$ is the length of the soil column.

The transport parameters, dispersivity $(\alpha)[L]$ and partition coefficient between the liquid and solid phases $\left(\mathrm{K}_{\mathrm{d}}\right)\left[\mathrm{L}^{3} \mathrm{M}^{-1}\right]$ were also determined as explained next.

The advection-dispersion equation (ADE) (Freeze and Cherry, 1979) used to interpret the BTCs is

$$
R \frac{\partial C}{\partial t}=D \frac{\partial^{2} C}{\partial x^{2}}-v \frac{\partial C}{\partial x},
$$

where $C$ is solute concentration $\left[\mathrm{ML}^{-3}\right], \mathrm{D}$ is the hydrodynamic dispersion coefficient $\left[\mathrm{M}^{2} \mathrm{~T}^{-1}\right], \mathrm{R}$ is the retardation factor $[-], x$ is distance $[L]$, and $t$ is time $[T]$.

The hydrodynamic dispersion coefficient is related to the a by (Freeze and Cherry, 1979) 


$$
D=\alpha \cdot v,
$$

and the retardation factor is related to the $\mathrm{K}_{d}$ through the expression (Freeze and Cherry, 1979)

$$
\mathrm{R}=1+\frac{\rho_{\mathrm{d}}}{\mathrm{n}} \mathrm{K}_{\mathrm{d}}
$$

The ADE has the following analytical solution (Lapidus and Amundson, 1952) when the initial condition is $C(x, 0)=0$ for the entire sample, and the boundary conditions are $C=C_{0}$ at the inlet and $\mathrm{C}=0$ at an infinite distance from the inlet

$$
\frac{C}{C_{0}}=\frac{1}{2}\left[\operatorname{erfc}\left(\frac{R L-v t}{2 \sqrt{D R t}}\right)\right]+\frac{1}{2} \exp \left(\frac{v L}{D}\right) \operatorname{erfc}\left(\frac{R L+v t}{2 \sqrt{D R t}}\right)
$$

where erfc is the complementary error function.

This expression was fitted to the observed BTCs for each soil sample and values of $D$ and $R$ were obtained for both $\mathrm{K}^{+}$and $\mathrm{Cl}^{-}$. The fitting was performed using the computer program CFITM (van Genuchten, 1980), that is part of the Windows-based computer software package Studio of Analytical Models (STANMOD) (Šimůnek et al., 1999). The fit of the experimental BTC to the ADE model was evaluated by its $R^{2}$. Most $B T C$ s presented significant tailing, $R^{2}$ ranged from 0.77 to 0.99 with a mean of 0.92 . We conclude that the ADE model is suitable to describe the experimental data.

From the values of $D$ and $R$ obtained after the fitting, the values of the $\alpha$ and the $K_{d}$ were calculated using Eq. (2) and (3), respectively.

\subsection{Field experiments}

Following, field experiments are described. Notice that solute transport experiments were not conducted in the field, only flow experiments.

\section{i.Double-ring infiltrometer (DRI)}

In the study area, seven double-ring infiltrometer tests (DRI) were conducted according to ASTM D3385-118 (ASTM, 2018). The DRIs used are made up of two concentric stainless-steel rings, with diameters of $0.30 \mathrm{~m}$ and $0.60 \mathrm{~m}$. The height of water in the inner ring was $0.15 \mathrm{~m}$ in all tests. The water level in a Mariotte tube was measured at preset time intervals. The DRI experiments were carried out until steady-state flow was reached, that is when discharge changes were $<0.5 \%$ over a 5 -minute interval. The duration of the tests ranged between 135 and 192 minutes. The infiltration rate was calculated on the basis of the observations. Empirical relations 
show that the infiltration rate decreases with time and tends to an asymptotic value, generally equal to the K (Fatehnia et al., 2016).

\section{ii.Infiltration in rectangular ditches}

The infiltration in rectangular ditches was done by using the modified inversed auger-hole method (Porchet's method) proposed by Stibinger (2014). According to this method, we used rectangular infiltration ditch with width $a[L]$ and length $b[L]$. The total infiltration flow (through the bottom and sides of the ditch) $\left[\mathrm{L}^{3} \mathrm{~T}^{-1}\right]$ can be measured by the variation in time of the volume of water in the ditch. If the water level is $h$, the volume water in the ditch is given by

$$
\mathrm{V}=\mathrm{abh} \text {, }
$$

and, since width and length do not change in time, the infiltration flow results

$$
Q=(a b) \frac{d h}{d t} .
$$

Assuming that the distance from the bottom of the ditch to the wetting front is large compared to the initial water level in the ditch $\left(h_{0}\right)$, then the hydraulic gradient approximates unity. In which case, if the Darcy Law is valid and the wetted soil below the ditch is practically saturated, the flux in the wetted soil approaches its $\mathrm{K}$.

Total infiltration (TI) in the ditch can be expressed as the sum of the infiltration through the bottom and the infiltration through the sides

$$
\mathrm{Tl}=\mathrm{BI}+\mathrm{Wl} \text {. }
$$

The total area through which flow occurs is the sum of the bottom area (ab) plus the area on the sides (2ah+2bh). Darcy's law states that total flow is $Q=-K i$, where $i$ is the hydraulic gradient (equal to one in our case), and $A$ is the flowing area, therefore,

$$
\mathrm{BI}+\mathrm{WI}=-(\mathrm{ab}+2(\mathrm{a}+\mathrm{b}) \mathrm{h}) \mathrm{K},
$$

where the negative sign indicates that the z-axis is positive upwards, but water flow is downwards. By combining Eq. (6) and (8), we obtain

$$
\text { (ab) } \frac{d h}{d t}=-(a b+2(a+b) h) K \text {, }
$$

which, after integration, yields 


$$
K\left(t_{m}-t_{j}\right)=-\frac{a b}{2(a+b)} \ln \left[\frac{h_{m}+\frac{a b}{2(a+b)}}{h_{j}+\frac{a b}{2(a+b)}}\right],
$$

where $h_{j}$ is the water level at time $t_{j}$ and $h_{m}$ is the water level at time $t_{m}$.

Eq. (10) can be rewritten by substituting $B=a b / 2(a+b)$

$$
K\left(t_{m}-t_{j}\right)=-B \ln \left[\frac{h_{m}+B}{h_{j}+B}\right],
$$

Replacing $h_{0}$ for $t_{0}=0$, the equation results

$$
\mathrm{Kt}^{*}=-\mathrm{B} \ln \left[\frac{\mathrm{h}^{*}+\mathrm{B}}{\mathrm{h}_{0}+\mathrm{B}}\right],
$$

where $\mathrm{h}^{*}$ is the water level at time $\mathrm{t}^{*}$, from which the expression of the evolution of water level with time is

$$
\mathrm{h}^{*}=\frac{\mathrm{h}_{0}+\mathrm{B}}{\exp \frac{\mathrm{Kt}}{\mathrm{B}}}-\mathrm{B},
$$

K can de deduced from the fitting of Eq. (13) to the observed water level decline in time.

We conducted falling-head infiltration tests in rectangular ditches of $0.70 \mathrm{~m}$ width by 0.40 $\mathrm{m}$ depth and five different lengths: $1 \mathrm{~m}, 2 \mathrm{~m}, 4 \mathrm{~m}, 6 \mathrm{~m}$, and $8 \mathrm{~m}$. All tests were performed twice with an interval of two weeks between the first and the second test. Before starting the measurements, the soil was saturated by continuously introducing water for one hour, using a water truck. The initial water height in the ditch, $h_{0}$, was set to $0.19 \mathrm{~m}$ for all ditches. Total infiltration time ranged from 60 to 90 minutes. Non-linear regression analysis using MATLAB function Isqcurvefit was used to fit Eq. (13) to the data and to determine the value of K. Water evaporation was measured and the infiltration flow was corrected when necessary.

\subsection{Results and discussion}

\section{iii.Soil characterization}

The physical characterization of the 55 small-scale undisturbed soil samples is summarized in statistical terms in Table 2. It is noticeable that the soil presents a significant variability (Wilding and Drees, 1983) for some properties such as macroporosity and silt content. Our results confirm that soil heterogeneity is present even on a small scale (Chapuis et al., 2005). Properties such as 
porosity and dry density were more homogeneous and presented only a small variability. The highest percentages of pore diameters found in the soil correspond to mesoporosity and microporosity. The multimodal pore size distribution is characteristic of well-structured soils (Lipiec et al., 2007) and can influence water flow and solute transport in these soils. Fig. 1 shows the results of three MIP tests performed with samples taken at $0.5 \mathrm{~m}, 1.0 \mathrm{~m}$, and $1.5 \mathrm{~m}$ depth: dual-porosity is evident.

Regarding the granulometric analyses, when the soil sample was prepared with deflocculant the soil is texturally classified as a clayey fine sand. But when the soil was analyzed in its natural condition, that is, no deflocculant was used, its texture is completely different, resulting in a coarser textural class. This behavior indicates the presence of aggregates in the soil, a characteristic of lateritic soils that can play an important role in water flow and solute transport. We also obtained a low CEC of $4.20 \mathrm{cmolc} \mathrm{Kg}^{-1}$, indicative of a soil with low capacity to adsorb cations by electrostatic adsorption (Fagundes and Zuquette, 2011). Finally, the mean values of the soil physical properties were in accordance with typical values found earlier in this type of soil (Giacheti et al., 1993).

To better understand the solute transport results, soil mineralogy, physico-chemical and chemical properties were also investigated. According to results of the X-ray diffraction, the main minerals present in the soil are quartz, kaolinite, and gibbsite. The soil can be considered as strongly acidic, with average values of 5.71 and 5.19 for $\mathrm{pH}$ in $\mathrm{H}_{2} \mathrm{O}$ and in $\mathrm{KCl}$, respectively. Cenozoic sediments and lateritic soils are commonly acidic (Giacheti et al., 1993). Important properties related to solute transport are the negative $\Delta \mathrm{pH}(-0.52)$ and the point of zero charge (PZC) (4.67) that indicates a predominance of negative charges, resulting in important cation adsorption (Fagundes and Zuquette, 2011). The average of the amount of organic matter was small $(2.40 \%)$, result in accordance with lateritic acid soils.

\section{iv.Evaluation of the scale dependence in the hydraulic conductivity}

Basic statistics of $\mathrm{K}$ were inferred from the 55 small-scale column experiments obtaining mean and standard deviation (SD) of $1.35 \mathrm{~m} / \mathrm{d}$ and $1.65 \mathrm{~m} / \mathrm{d}$, respectively. The coefficient of variation (CV) was 1.22 and indicates a highly variable parameter (Wilding and Drees, 1983). We expect scale effects since these are mostly related to the degree of heterogeneity (Sánchez-Vila et al. 1996). 
The mean $\mathrm{K}$ values obtained from the large-scale column experiments were calculated for each set of samples. Previous studies have shown that scale effects are dependent on the sample volume (Al-Raoush and Papadopoulos, 2010; Valdés-Parada et al., 2012). But, before analyzing that dependence, we have analyzed if there are scale effects associated with the column height or the column diameter. Fig. 2 ( $\mathrm{A}-\mathrm{B}$ ) shows the variation of $\mathrm{K}$ with column height and diameter. Average $\mathrm{K}$ values ranged between $1.35 \mathrm{~m} / \mathrm{d}$ and $2.1 \mathrm{~m} / \mathrm{d}$. These differences can be considered moderate for water flow modeling, but they can be significant for solute transport predictions. Average $\mathrm{K}$ increased with the sample diameter. $\mathrm{K}$ seems to increase with height, except for the samples with a diameter of $0.2 \mathrm{~m}$, for which no clear trend was verified. Only a small range of diameters and heights were analyzed in this research, so these results should be taken as only indicative.

Fig. 3 (A-B) shows the infiltration rate as a function of time for seven double-ring infiltrometer tests. We can see that all tests behave similarly, although they have very different transition zones. The infiltration rate decreases rapidly at the beginning of the test, as expected due to high potential differences, then it tends to a limiting value that can be assimilated to the soil $\mathrm{K}$. Doublering infiltrometer tests resulted in $\mathrm{K}$ values ranging from $0.104 \mathrm{~m} / \mathrm{d}$ to $0.538 \mathrm{~m} / \mathrm{d}$, with a mean value equal to $0.36 \mathrm{~m} / \mathrm{d}$, $S D$ is equal to $0.147 \mathrm{~m} / \mathrm{d}$ and the $\mathrm{CV}$ is 0.45 , showing a moderate heterogeneity that, as discussed before, is present at all scales. Fig. 3B is a zoom in Fig. 3A to show the transition zones, where the greatest variability happens.

Fig. 4 shows the reduction of the water table with time in the two tests performed in each ditch. From these curves, $\mathrm{K}$ was determined using Eq. (13). Very similar results were obtained for each pair of tests performed in the same ditch. It is possible to see that the slope of the curves increases as the ditch length increases, indicating that the water level lowers faster as the test scale increases and, therefore, the $\mathrm{K}$ for the test tends to increase, with the exception of the ditch of $4 \mathrm{~m}$ length, which has the smallest slope. $K$ values ranged from $1.44 \mathrm{~m} / \mathrm{d}$ to $6.04 \mathrm{~m} / \mathrm{d}$, with a mean equal to $2.7 \mathrm{~m} / \mathrm{d}$ and a SD of $1.68 \mathrm{~m} / \mathrm{d}$.

The scale effect on $\mathrm{K}$ was evaluated by analyzing the $\mathrm{K}$ values against the sample support, that is, against the volume of the sample for which $\mathrm{K}$ was evaluated. For the small-scale samples, the sample volume is simply the permeameter volume, and for the DRI and the ditches, the sample support was the volume of saturated soil. The depth of the saturated zone was determined by taking soil samples every $0.2 \mathrm{~m}$, immediately after the tests, to determine the soil moisture. The average saturated depth of all tests was $0.5 \mathrm{~m}$ and this value was used in the calculation of the volume of saturated soil. 
Fig. 5 (A-C) shows the variation of $\mathrm{K}$ with sample volume. According to these results, $\mathrm{K}$ seems to increase with scale, despite some oscillations. Laboratory tests were performed after the removal of entrapped air, that can reduce in the $\mathrm{K}$, by slowly saturate the samples from the bottom. However, in the field tests, the removal of the entrapped air cannot be assured, although soil saturation before the ditches infiltration tests. This can justify the results obtained for the DRI tests that give mean $\mathrm{K}$ value lower than that obtained at the laboratory, even though the volume of $\mathrm{DRI}$ sample is bigger than the volume of sample used in the laboratory experiments (Fig $5 \mathrm{~A}$ ). We are aware that laboratory and field experiments were not performed at the same conditions and comparisons between such data from different test conditions cannot be appropriate and the results obtained from laboratory and field test are then show separately. Fig. 5B shows the results only for the laboratory tests and Fig. $5 \mathrm{C}$ shows the results only for the field tests. In these figures, we can see for each test condition, $\mathrm{K}$ increases with the sample volume. Similar results were also observed by other researchers (Chapuis et al., 2005; Lai and Ren, 2007; Sobieraj et al., 2004; Tidwell, 2006) who attribute it to the high $\mathrm{K}$ features that are not present at small scales. We conclude that, for the same measurement condition, there is scale effect on $\mathrm{K}$ since observed $\mathrm{K}$ values depend on the volume sampled. In general, the $\mathrm{K}$ obtained at the laboratory were lower than that obtained at the field, however, these results cannot be conclusive since the difference in test conditions can influence the responses (Neuman, 1994; Tidwell, 2006).

The variation of the $\mathrm{K}$ with the sample volume must be taken into account when these observations are later used as input to numerical models. The numerical model must be constructed with elements of a size similar to that at which the data were collected, otherwise, some upscaling rule must be used when observation and model scales are different (Huang and Griffiths, 2015; Li et al., 2011).

\section{v.Evaluation of the scale dependence in the transport parameters}

Dispersivity and partition coefficient for $\mathrm{Cl}^{-}$and $\mathrm{K}^{+}$from 55 miscible displacements tests in small-scale undisturbed soil samples were determined, and their values are summarized in Table 3. These parameters display high variability as a consequence of its heterogeneity (Alletto and Coquet, 2009; Sánchez-Vila et al., 1996). The cation $\left(\mathrm{K}^{+}\right) \mathrm{K}_{d}$ were greater than the anion $\left(\mathrm{Cl}^{-}\right)$ ones, in agreement with the soil characteristics that do not favor anion adsorption, given the low amount of organic matter and the negative charges in the surface of the soil particles. Fig. 6A-C show BTCs of $\mathrm{K}^{+}$and $\mathrm{Cl}^{-}$obtained experimentally for some of the small and large soil samples studied. 
The cation $\alpha$ values were also higher than the anion ones. These results are illustrated in Fig. 6A where experimental BTCs of $\mathrm{K}^{+}$and $\mathrm{Cl}^{-}$obtained in two of the 55 miscible displacement tests are shown. $\mathrm{K}^{+}$moves slower than $\mathrm{Cl}^{-}$, resulting in larger $\mathrm{R}$ and $\mathrm{K}_{\mathrm{d}}$. The fitted values for the $\mathrm{K}_{d}$ are high, even for $\mathrm{Cl}^{-}$, which is a nonreactive solute. Since the mineralogical and physicochemical characteristics of the soil cannot justify high $\mathrm{R}$ values, we argue that the soil structure and other physical characteristics, such as dual-porosity and particle aggregates, are playing an important role in the retention. For example, small pores can favor the formation of immobile domains where mass can temporarily be trapped, decreasing its velocity, in relation to the velocity of the flow, and increasing its R (Dousset et al., 2007; Jarvis, 2007; Silva et al., 2016).

The statistics of $\alpha$ and $\mathrm{K}_{d}$ for $\mathrm{K}^{+}$and $\mathrm{Cl}^{-}$derived from the analysis of large-scale miscible displacements tests are shown in Tables 4 and 5 . These results agree with those obtained in small-scale experiments and display high variability. As in the small-scale tests, mean values for $\mathrm{K}^{+}$were greater than those for $\mathrm{Cl}^{-}$. From these tables, it is noticeable that $\mathrm{Cl}^{-} \mathrm{K}_{d}$ are smaller than those for $\mathrm{K}^{+}$and, therefore, moves faster than $\mathrm{K}^{+}$. Fig. 6B and Fig. 6C shows, for each sample size, BTCs of $\mathrm{K}^{+}$and $\mathrm{Cl}^{-}$, respectively, for one of the tests. The $\mathrm{S}$ shape of the BTCs is also indicative of the important role that dispersion plays as a transport mechanism in the studied soil, which can be readily related to small-scale heterogeneity (Gerritse, 1996).

Fig. 7 shows how a varies as a function of the sample height (that is, length in the solute transport direction), diameter and volume. As expected (Fetter, 1999; Freeze and Cherry, 1979), dispersivities tend to increase with the scale, and this trend can be fitted with the following exponential functions: $\alpha=0.12 e^{2.55 x}\left(R^{2} 0.95\right)$ for $\mathrm{K}^{+}$and $\alpha=0.05 \mathrm{e}^{3.52 x}\left(\mathrm{R}^{2} 0.93\right)$ for $\mathrm{Cl}^{-}$. This behavior can be attributed to heterogeneous arrangements in the soil sample since at larger scales a larger number of heterogeneities can be found inducing a higher a. Gelhar (1987) postulated that longitudinal dispersivity should initially increase linearly with distance and eventually reach a constant asymptotic value. Gelhar and Axness (1983) concluded that $\alpha$ is related to the distance through the expression $\alpha=0.1 \mathrm{x}$, where $\mathrm{x}$ is the travel distance. Later, Gelhar et al. (1992) observed that the linear relationship between $\alpha$ and travel distance should be reconsidered. Vik et al. (2013) found a linear relation between $\alpha$ and distance, but their data resulted in a lower slope $(\alpha=0.07 x)$ than the one suggested by Gelhar and Axness' expression. $\mathrm{Xu}$ and Eckstein (1995) studied some regression formulas relating $\alpha$ and distance, and defined a relationship between $\alpha$ and field scale in the form $\alpha=0.83[\log x]^{2.414}$ and mentioned that the slope of the curve approaches zero when the scale exceeds $1 \mathrm{~km}$. Regarding the dependency of $\alpha$ with 
sample diameter and sample volume, the results in Fig. 7 show no clear dependence and the oscillations of data prevented a good fit by simple monotonic functions, with $\mathrm{R}^{2}$ below 0.05 when attempting to fit $\alpha$ to sample diameter. When trying to fit a monotonic function of $\alpha$ as a function of sample volume, the $\mathrm{R}^{2}$ equals 0.4 and 0.3 for $\mathrm{K}^{+}$and $\mathrm{Cl}^{-}$, respectively. From a practical point of view, these results should serve as a cautionary note about routinely adopting $\alpha$ from a linear regression without further considerations; otherwise, excessively large or small dilution may be induced in solute transport predictions, and the environmental responses misrepresented.

Fig. 8 shows how $\mathrm{K}_{d}$ varies as a function of the sample height (length in the solute transport direction), diameter and volume. The $\mathrm{K}_{d}$ of $\mathrm{K}^{+}$tends to increase with length, diameter and volume (most clearly with the latter one), and the same can be said for the $\mathrm{K}_{d}$ of $\mathrm{Cl}^{-}$. On one hand, the fit of $\mathrm{K}_{d}$ to sample height is poor for both $\mathrm{K}^{+}$and $\mathrm{Cl}^{-}$, with $\mathrm{R}^{2}$ of 0.19 and 0.08 , respectively. On the other hand, $K_{d}$ displays a clear trend as a function of sample diameter, which can be fitted with the following functions: $K_{d}=14.2 x^{0.40}\left(R^{2} 0.81\right)$ for $\mathrm{K}^{+}$, and $\mathrm{K}_{d}=2.43 \ln (\mathrm{x})+8.13\left(\mathrm{R}^{2} 0.82\right)$ for $\mathrm{Cl}^{-}$, where $\mathrm{x}$ is the dependent variable (height, diameter or volume of the sample). In addition, $K_{d}$ also displays a clear trend with sample volume, with the following linear functions: $K_{d}=158 x+5.2\left(R^{2}\right.$ 0.95) for $\mathrm{K}^{+}$and $\mathrm{K}_{d}=124 \mathrm{x}+2.3\left(\mathrm{R}^{2} 0.70\right)$ for $\mathrm{Cl}^{-}$. With these results, it is noticeable that $\mathrm{K}_{d}$ of $\mathrm{K}^{+}$ and $\mathrm{Cl}^{-}$do not reach a stable value with any of the dimensions studied here. The clear dependence on sample volume can be explained for the larger number of sorption sites as the volume increases together with the larger heterogeneity of those sites.

\subsection{Conclusions}

Small and large-scale laboratory experiments and field experiments were performed in order to study scale effects on hydraulic conductivity $(K)$, dispersivity $(\alpha)$ and partition coefficient $\left(K_{d}\right)$ in a tropical soil from Brazil. The studied soil was characterized in detail. Small and large-scale undisturbed soil samples were used to perform column experiments to determine $\mathrm{K}$, $\alpha$, and $\mathrm{K}_{\mathrm{d}}$. Seven-double ring infiltrometer tests and five infiltration tests in rectangular ditches were also done to determine $\mathrm{K}$.

The soil has dual-porosity and contains aggregates, a characteristic of lateritic soils that probably played an important role in the soil $\mathrm{K}$, $\alpha$ and $\mathrm{K}_{\mathrm{d}}$ values. Due to its low CEC, the soil has a low capacity to adsorb cations by electrostatic adsorption. However, the predominance of negative charges in the soil particles surface favored cation adsorption. The coefficients of variation obtained in all laboratory and field tests indicated that $K, \alpha$, and $K_{d}$ are highly heterogeneous at all scales. In agreement with the soil characteristics, the cation $\left(\mathrm{K}^{+}\right) \mathrm{K}_{d}$ and $\alpha$ 
were greater than the anion $\left(\mathrm{Cl}^{-}\right)$ones. From the BTCs it is clear that $\mathrm{Cl}^{-}$moves faster than $\mathrm{K}^{+}$. The fitted values for the $\mathrm{K}_{d}$ are high, even for $\mathrm{Cl}^{-}$, which is considered a nonreactive solute. We attribute that result to the soil structure and physical characteristics.

Average $\mathrm{K}$ increased with sample support, for the same measurement condition, result attributed to the high heterogeneity and the high $\mathrm{K}$ features that are present in large scales but not at small scales. $\mathrm{K}^{+}$and $\mathrm{Cl}^{-}$a increases with travel distance, a behavior that can be fitted with exponential functions. We attribute this trend to heterogeneous arrangements in the soil sample since at larger scales there exist larger heterogeneities that induce higher $\alpha$. The results show that both the $\mathrm{K}_{d}$ of $\mathrm{K}^{+}$and $\mathrm{Cl}^{-}$tend to increase in all studied magnitudes. We argue that these results are due to the larger number of sorption sites as the sample support increases together with the larger heterogeneity of those sites.

Finally, this paper warns against the use of the $\mathrm{K}, \mathrm{\alpha}$, and $\mathrm{K}_{\mathrm{d}}$ in numerical models with no concern about the scale at which they were measured; not accounting for the difference of scale between observation and model may distort the predictions and compromise their reliability. 


\section{Acknowledgments}

The authors thank the financial support by the Brazilian National Council for Scientific and Technological Development (CNPq) (Project 401441/2014-8). The doctoral fellowship awarded to the first author by the Coordination of Improvement of Higher Level Personnel (CAPES) is gratefully acknowledged. The first author also thanks to the international mobility grant awarded by CNPq, through the Science Without Borders program (grant number: 200597/2015-9), and the international mobility grant awarded by Santander Mobility in cooperation with the University of São Paulo. 


\section{Bibliography}

Ahuja, L.R., Naney, J.W., Green, R.E., Nielsen, D.R., 1984. Macroporosity to Characterize Spatial Variability of Hydraulic Conductivity and Effects of Land Management1. Soil Sci. Soc. Am. J. 48, 699. doi:10.2136/sssaj1984.03615995004800040001x

Al-Raoush, R., Papadopoulos, A., 2010. Representative elementary volume analysis of porous media using X-ray computed tomography. Powder Technol. 200, 69-77. doi:10.1016/j.powtec.2010.02.011

Alletto, L., Coquet, Y., 2009. Temporal and spatial variability of soil bulk density and nearsaturated hydraulic conductivity under two contrasted tillage management systems. Geoderma 152, 85-94. doi:10.1016/j.geoderma.2009.05.023

ASTM, 2018. ASTM D3385 - 18, Standard Test Method for Infiltration Rate of Soils in Field Using Double-Ring Infiltrometer.

ASTM, 2017a. ASTM D7928-17, Standard Test Method for Particle-Size Distribution (Gradation) of Fine-Grained Soils Using the Sedimentation (Hydrometer) Analysis.

ASTM, 2017b. ASTM D6913 / D6913M-17, Standard Test Methods for Particle-Size Distribution (Gradation) of Soils Using Sieve Analysis. doi:10.1520/D6913_D6913M-17

ASTM, 2014a. ASTM D2974 - 14, Standard Test Methods for Moisture, Ash, and Organic Matter of Peat and Other Organic Soils. doi:10.1520/D2974-14

ASTM, 2014b. ASTM D854 - 14, Standard Test Methods for Specific Gravity of Soil Solids by Water Pycnometer. doi:10.1520/D0854-14

Azaroff, L., Buerger, M., 1953. The powder method in X-ray crystallography. New York. McGrawHill Book Co.

Bahaaddini, M., Hagan, P.C., Mitra, R., Hebblewhite, B.K., 2014. Scale effect on the shear behaviour of rock joints based on a numerical study. Eng. Geol. 181, 212-223. doi:10.1016/j.enggeo.2014.07.018

Bouchelaghem, F., Jozja, N., 2009. Multi-scale study of permeability evolution of a bentonite clay owing to pollutant transport. Eng. Geol. 108, 286-294. doi:10.1016/j.enggeo.2009.06.021

Butler, J.J., Healey, J.M., 1998a. Relationship Between Pumping-Test and Slug-Test Parameters: Scale Effect or Artifact? Ground Water 36, 305-312. doi:10.1111/j.17456584.1998.tb01096.x 
Butler, J.J., Healey, J.M., 1998b. Authors' Reply. Ground Water 36, 867-868. doi:10.1111/j.17456584.1998.tb02092.x

Cassiraga, E.F., Fernàndez-Garcia, D., Gómez-Hernández, J.J., 2005. Performance assessment of solute transport upscaling methods in the context of nuclear waste disposal. Int. J. Rock Mech. Min. Sci. 42, 756-764. doi:10.1016/j.jirmms.2005.03.013

Chapuis, R.P., Dallaire, V., Marcotte, D., Chouteau, M., Acevedo, N., Gagnon, F., 2005. Evaluating the hydraulic conductivity at three different scales within an unconfined sand aquifer at Lachenaie, Quebec. Can. Geotech. J. 42, 1212-1220. doi:10.1139/t05-045

Clauser, C., 1992. Permeability of crystalline rocks. Eos, Trans. Am. Geophys. Union 73, 233233. doi:10.1029/91EO00190

Domenico, P.A., Robbins, G.A., 1984. A dispersion scale effect in model calibrations and field tracer experiments. J. Hydrol. 70, 123-132. doi:10.1016/0022-1694(84)90117-3

Dou, H., Han, T., Gong, X., Zhang, J., 2014. Probabilistic slope stability analysis considering the variability of hydraulic conductivity under rainfall infiltration-redistribution conditions. Eng. Geol. 183, 1-13. doi:10.1016/j.enggeo.2014.09.005

Dousset, S., Thevenot, M., Pot, V., Šimunek, J., 2007. Evaluating equilibrium and non-equilibrium transport of bromide and isoproturon in disturbed and undisturbed soil columns. J. Contam. 94, 261-276. doi:10.1016/j.jconhyd.2007.07.002

Duong, T. V., Trinh, V.N., Cui, Y.J., Tang, A.M., Calon, N., 2013. Development of a Large-Scale Infiltration Column for Studying the Hydraulic Conductivity of Unsaturated Fouled Ballast. Geotech. Test. J. 36, 20120099. doi:10.1520/GTJ20120099

Fagundes, J.R.T., Zuquette, L.V., 2011. Sorption behavior of the sandy residual unconsolidated materials from the sandstones of the Botucatu Formation, the main aquifer of Brazil. Environ. Earth Sci. 62, 831-845. doi:10.1007/s12665-010-0570-y

Fatehnia, Tawfiq, K., Ye, M., 2016. Estimation of saturated hydraulic conductivity from doublering infiltrometer measurements. Eur. J. Soil Sci. 67, 135-147. doi:10.1111/ejss.12322

Fetter, C., 1999. Contaminant hydrogeology, 2nd ed. Prentice Hall, New York.

Freeze, R., Cherry, J., 1979. Groundwater (p. 604). PrenticeHall Inc Englewood cliffs, New Jersey.

Gelhar, L.W., Axness, C.L., 1983. Three-dimensional stochastic analysis of macrodispersion in aquifers. Water Resour. Res. 19, 161-180. doi:10.1029/WR019i001p00161 
Gelhar, L.W., Welty, C., Rehfeldt, K.R., 1992. A critical review of data on field-scale dispersion in aquifers. Water Resour. Res. 28, 1955-1974. doi:10.1029/92WR00607

Gerritse, R.G., 1996. Dispersion of cadmium in columns of saturated sandy soils. J. Environ. Qual. 25, 1344-1349.

Ghiglieri, G., Carletti, A., Da Pelo, S., Cocco, F., Funedda, A., Loi, A., Manta, F., Pittalis, D., 2016. Three-dimensional hydrogeological reconstruction based on geological depositional model: A case study from the coastal plain of Arborea (Sardinia, Italy). Eng. Geol. 207, 103-114. doi:10.1016/j.enggeo.2016.04.014

Giacheti, H.L., Rohm, S.A., Nogueira, J.B., Cintra, J.C.A., 1993. Geotechnical properties of the Cenozoic sediment (In protuguese), in: Albiero, J.H., Cintra, J.C.A. (Eds.), Soil from the Interior of São Paulo. ABMS, Sao Paulo, pp. 143-175.

Godoy, V.A., Valentin Zuquette, L., Gómez-Hernández, J.J., 2018. Stochastic analysis of threedimensional hydraulic conductivity upscaling in a heterogeneous tropical soil. Comput. Geotech. 100, 174-187. doi:10.1016/j.compgeo.2018.03.004

Godoy, V.A., Zuquette, L.V., Napa-García, G.F., 2015. Hydrodynamic dispersion coefficient of ammonium in undisturbed soil columns, in: Geotechnical Engineering for Infrastructure and Development. ICE publishing, pp. 2699-2703.

Gómez-Hernández, J.J., Fu, J., Fernandez-Garcia, D., 2006. Upscaling retardation factors in 2D porous media, in: Bierkens, M.F.P., Gehrels, J.C., Kovar, K. (Eds.), Calibration and Reliability in Groundwater Modelling : From Uncertainty to Decision Making : Proceedings of the ModelCARE 2005 Conference Held in The Hague, the Netherlands, 6-9 June, 2005. IAHS Publication, pp. 130-136.

Huang, J., Griffiths, D.V., 2015. Determining an appropriate finite element size for modelling the strength of undrained random soils. Comput. Geotech. 69, 506-513. doi:10.1016/j.compgeo.2015.06.020

Jarvis, N.J., 2007. A review of non-equilibrium water fl ow and solute transport in soil macropores: Principles, controlling factors and consequences for water quality. Eur. J. Soil Sci. 58, 523546. doi:10.4141/cjss2011-050

Keng, J.C., Uehara, G., 1973. Chemistry, mineralogy, and taxonomy of oxisols and ultisols. Proc. Soil Crop Sci. Soc. Florida 33, 119-926.

Khan, A.U.-H., Jury, W.A., 1990. A laboratory study of the dispersion scale effect in column 
outflow experiments. J. Contam. Hydrol. 5, 119-131. doi:10.1016/0169-7722(90)90001-W

Knappett, J., Craig, R.F., 2012. Craig's Soil Mechanics, 8th ed. CRC Press.

Koorevaar, P., Menelik, G., Dirksen, C., 1983. Elements of Soil Physics, 1st ed, Developments in Soil Science. Elsevier Science. doi:10.1016/S0166-2481(08)70048-5

Lai, J., Ren, L., 2007. Assessing the Size Dependency of Measured Hydraulic Conductivity Using Double-Ring Infiltrometers and Numerical Simulation. Soil Sci. Soc. Am. J. 71, 1667. doi:10.2136/sssaj2006.0227

Lapidus, L., Amundson, N., 1952. Mathematics of adsorption in beds VI. The effect of longitudinal diffusion in ion exchange and chromatographic columns. J. Phys. Chem. 984-988. doi:10.1021/j150500a014

Latorre, B., Peña, C., Lassabatere, L., Angulo-Jaramillo, R., Moret-Fernández, D., 2015. Estimate of soil hydraulic properties from disc infiltrometer three-dimensional infiltration curve. Numerical analysis and field application. J. Hydrol. 527, 1-12. doi:10.1016/j.jhydrol.2015.04.015

Li, L., Zhou, H., Gómez-Hernández, J.J., 2011. A comparative study of three-dimensional hydraulic conductivity upscaling at the macro-dispersion experiment (MADE) site, Columbus Air Force Base, Mississippi (USA). J. Hydrol. 404, 278-293. doi:10.1016/j.jhydrol.2011.05.001

Lipiec, J., Walczak, R., Witkowska-Walczak, B., Nosalewicz, A., Słowińska-Jurkiewicz, A., Sławiński, C., 2007. The effect of aggregate size on water retention and pore structure of two silt loam soils of different genesis. Soil Tillage Res. 97, 239-246. doi:10.1016/j.still.2007.10.001

Liu, J., Huang, X., Liu, J., Wang, W., Zhang, W., Dong, F., 2014. Adsorption of arsenic(V) on bone char: batch, column and modeling studies. Environ. Earth Sci. 72, 2081-2090. doi:10.1007/s12665-014-3116-x

Mekaru, T., Uehara, G., 1972. Anion adsorption in ferruginous tropical soils. Soil Sci. Soc. Am.

Navarro, V., Yustres, Á., Asensio, L., la Morena, G. De, González-Arteaga, J., Laurila, T., Pintado, X., 2017. Modelling of compacted bentonite swelling accounting for salinity effects. Eng. Geol. 223, 48-58. doi:10.1016/j.enggeo.2017.04.016

Neuman, S.P., 1994. Generalized scaling of permeabilities: Validation and effect of support scale. Geophys. Res. Lett. 21, 349-352. doi:10.1029/94GL00308 
Parker, J.C., Albrecht, K.A., 1987. Sample volume effects on solute transport predictions. Water Resour. Res. 23, 2293-2301. doi:10.1029/WR023i012p02293

Pejon, O., 1992. Mapeamento geotécnico regional da folha de Piracicaba (SP): Estudos de aspectos metodológicos de caracterização e apresentação de atributos. Universidade de São Paulo, Tese de doutorado (in Portuguese). University of São Paulo.

Rohm, S.A., 1992. Shear strength of a non-saturated lateritic sandy soil in the São Carlos region (In portuguese). University of Sao Paulo.

Salamon, P., Fernàndez-Garcia, D., Gómez-Hernández, J.J., 2007. Modeling tracer transport at the MADE site: The importance of heterogeneity. Water Resour. Res. 43. doi:10.1029/2006WR005522

Sánchez-Vila, X., Carrera, J., Girardi, J.P., 1996. Scale effects in transmissivity. J. Hydrol. 183, 1-22. doi:10.1016/S0022-1694(96)80031-X

Silva, L.P. da, van Lier, Q. de J., Correa, M.M., Miranda, J.H. de, Oliveira, L.A. de, 2016. Retention and Solute Transport Properties in Disturbed and Undisturbed Soil Samples. Rev. Bras. Ciência do Solo 40. doi:10.1590/18069657rbcs20151045

Šimůnek, J., van Genuchten, M.T., Šejna, M., Toride, N., Leij, F.J., 1999. The STANMOD Computer Software for Evaluating Solute Transport in Porous Media Using Analytical Solutions of Convection-Dispersion Equation. Riverside, California.

Sobieraj, J.A., Elsenbeer, H., Cameron, G., 2004. Scale dependency in spatial patterns of saturated hydraulic conductivity. Catena 55, 49-77. doi:10.1016/S0341-8162(03)00090-0

Stibinger, J., 2014. Examples of Determining the Hydraulic Conductivity of Soils Theory and Applications of Selected Basic Methods. Jan Evangelista Purkyně University Faculty of the Environment.

Tidwell, V.C., 2006. Scaling Issues in Porous and Fractured Media, in: Gas Transport in Porous Media. Springer Netherlands, pp. 201-212. doi:10.1007/1-4020-3962-X_11

Valdés-Parada, F.J., Varela, J.R., Alvarez-Ramirez, J., 2012. Upscaling pollutant dispersion in the Mexico City Metropolitan Area. Phys. A Stat. Mech. its Appl. 391, 606-615. doi:10.1016/j.physa.2011.08.017

van Genuchten, M.T., 1980. Determining transport parameters from solute displacement experiments.

Vik, B., Bastesen, E., Skauge, A., 2013. Evaluation of representative elementary volume for a 
vuggy carbonate rock—Part: Porosity, permeability, and dispersivity. J. Pet. Sci. Eng. 112, 36-47. doi:10.1016/j.petrol.2013.03.029

Wang, W., Wang, Y., Sun, Q., Zhang, M., Qiang, Y., Liu, M., 2017. Spatial variation of saturated hydraulic conductivity of a loess slope in the South Jingyang Plateau, China. Eng. Geol. doi:10.1016/j.enggeo.2017.08.002

Washburn, E.W., 1921. Note on a method of determining the distribution of pore sizes in a porous material. Proc. Natl. Acad. Sci. U. S. A. 7, 115-116. doi:10.1073/pnas.7.4.115

Wilding, L.P., Drees, L.R., 1983. Spatial variability and pedology, in: Wilding, L.P., Smeck, N.E., Hall, G.F. (Eds.), Pedogenesis and Soil Taxonomy: The Soil Orders. Elsevier, Netherlands, pp. 83-116.

Xu, M., Eckstein, Y., 1995. Use of Weighted Least-Squares Method in Evaluation of the Relationship Between Dispersivity and Field Scale. Ground Water 33, 905-908. doi:10.1111/j.1745-6584.1995.tb00035.x

Yang, T., Liu, H.Y., Tang, C.A., 2017. Scale effect in macroscopic permeability of jointed rock mass using a coupled stress-damage-flow method. Eng. Geol. 228, 121-136. doi:10.1016/j.enggeo.2017.07.009

Yilmaz, E., Belem, T., Benzaazoua, M., 2015. Specimen size effect on strength behavior of cemented paste backfills subjected to different placement conditions. Eng. Geol. 185, 5262. doi:10.1016/j.enggeo.2014.11.015

Yoshinaka, R., Osada, M., Park, H., Sasaki, T., Sasaki, K., 2008. Practical determination of mechanical design parameters of intact rock considering scale effect. Eng. Geol. 96, 173186. doi:10.1016/j.enggeo.2007.10.008 
List of Figures

Fig. 1 Results of three MIP tests: frequency of pore diameters for samples taken at $0.5 \mathrm{~m}, 1.0 \mathrm{~m}$, and $1.5 \mathrm{~m}$ depth

Fig. 2 Variation of average hydraulic conductivity with sample diameter (A) and height (B)

Fig. 3 A) Results of seven double-ring infiltrometer tests; B) a zoom in Fig. 4A to show the transition zones, the region of greatest variability

Fig. 4 Evolution of the water table in the ditches with time in tests 1 and 2

Fig. 5 Variation of $\mathrm{K}$ with measurement scale A) all testes; B) only laboratory tests; C) only field tests (double ring infiltrometer and ditch infiltration)

Fig. $6 \mathrm{~A}$ ) Breakthrough curves of $\mathrm{Cl}^{-}$and $\mathrm{K}^{+}$for two miscible displacement experiments performed in small-scale samples; B) Breakthrough curves of $\mathrm{K}^{+}$from one of the miscible displacement experiments in each large-scale sample size; C) Breakthrough curves of $\mathrm{Cl}^{-}$from one of the miscible displacement experiments in each large-scale sample size

Fig. 7 Variation of the dispersivity of $\mathrm{K}^{+}$and $\mathrm{Cl}^{-}$with sample height, diameter and volume

Fig. 8 Variation of the partition coefficient of $\mathrm{K}^{+}$and $\mathrm{Cl}^{-}$with sample height, diameter and volume 
Figure 1

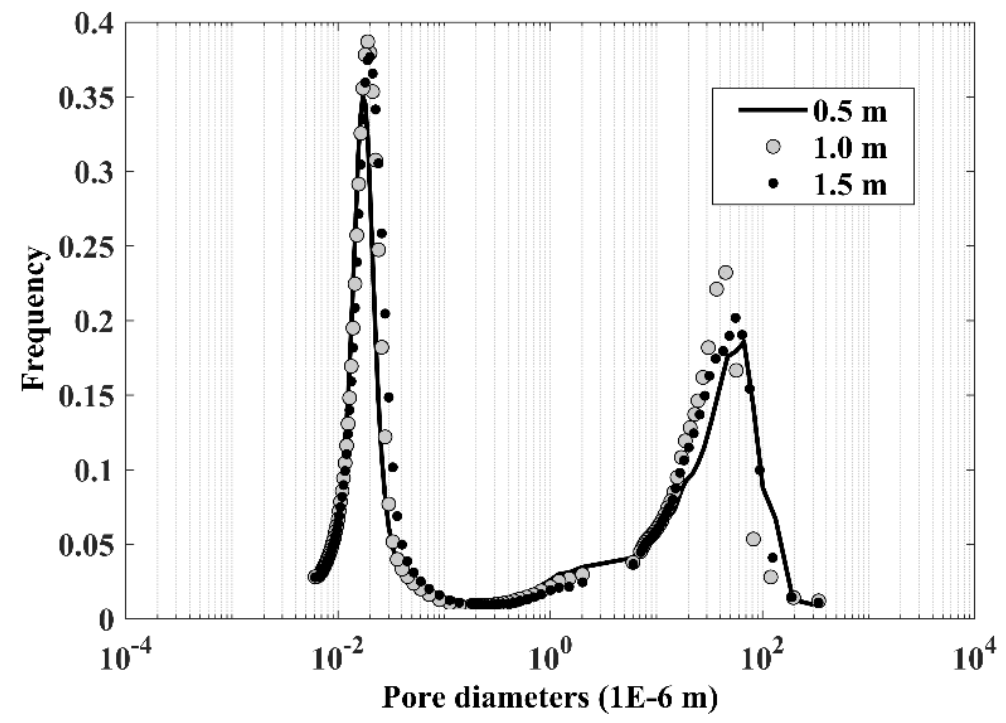


Figure 2
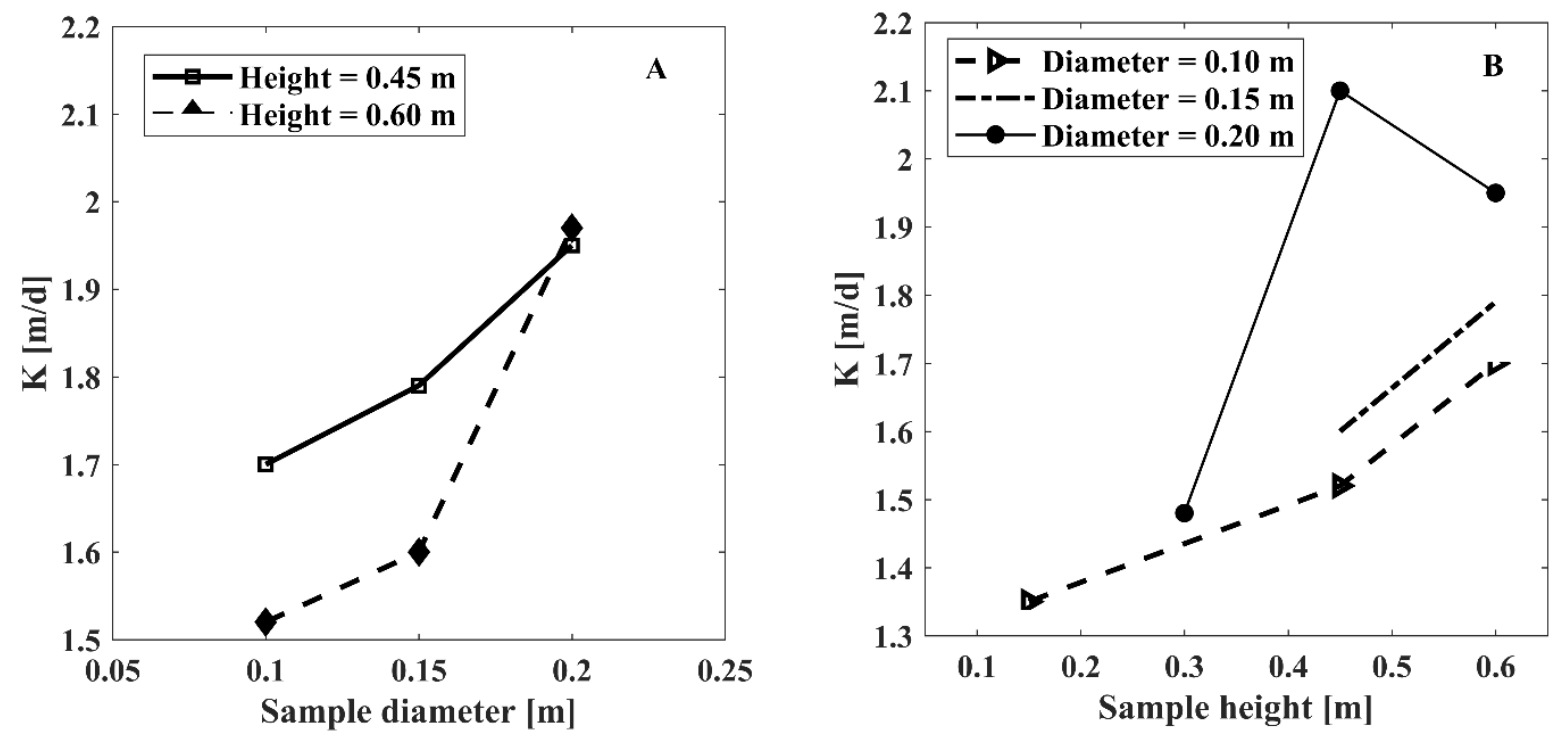
Figure 3
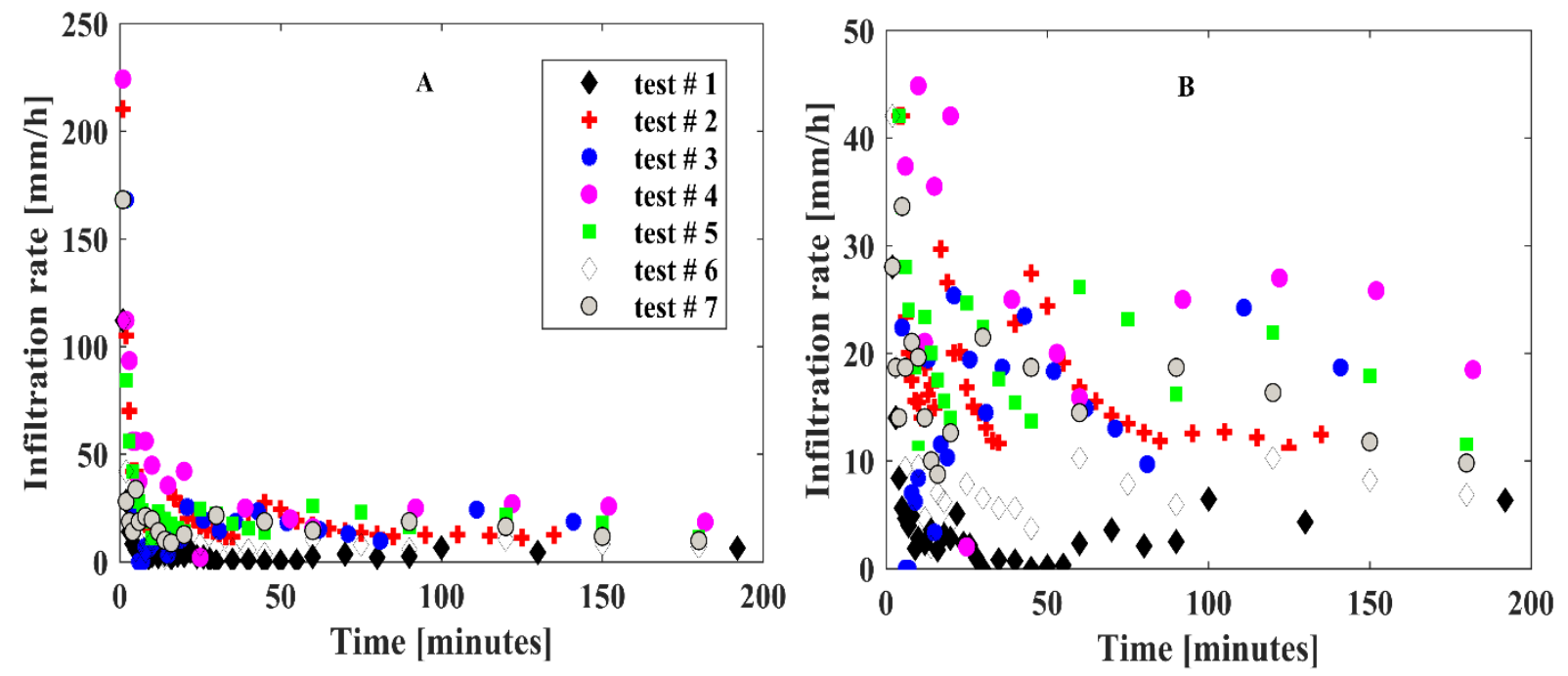
Figure 4

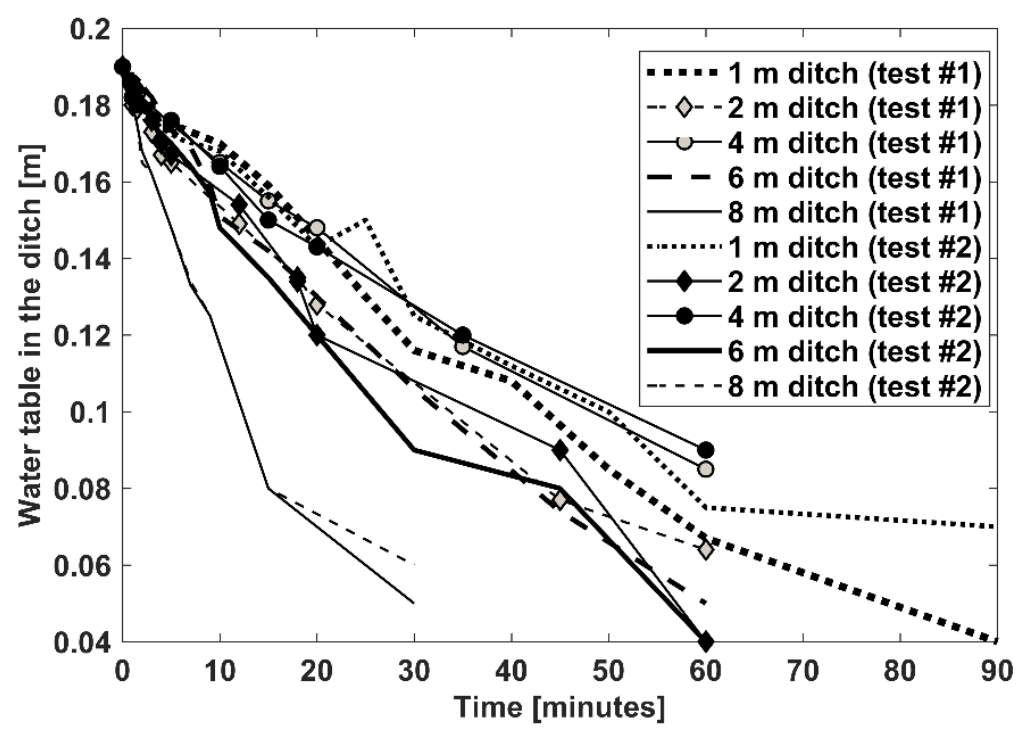


Figure 5
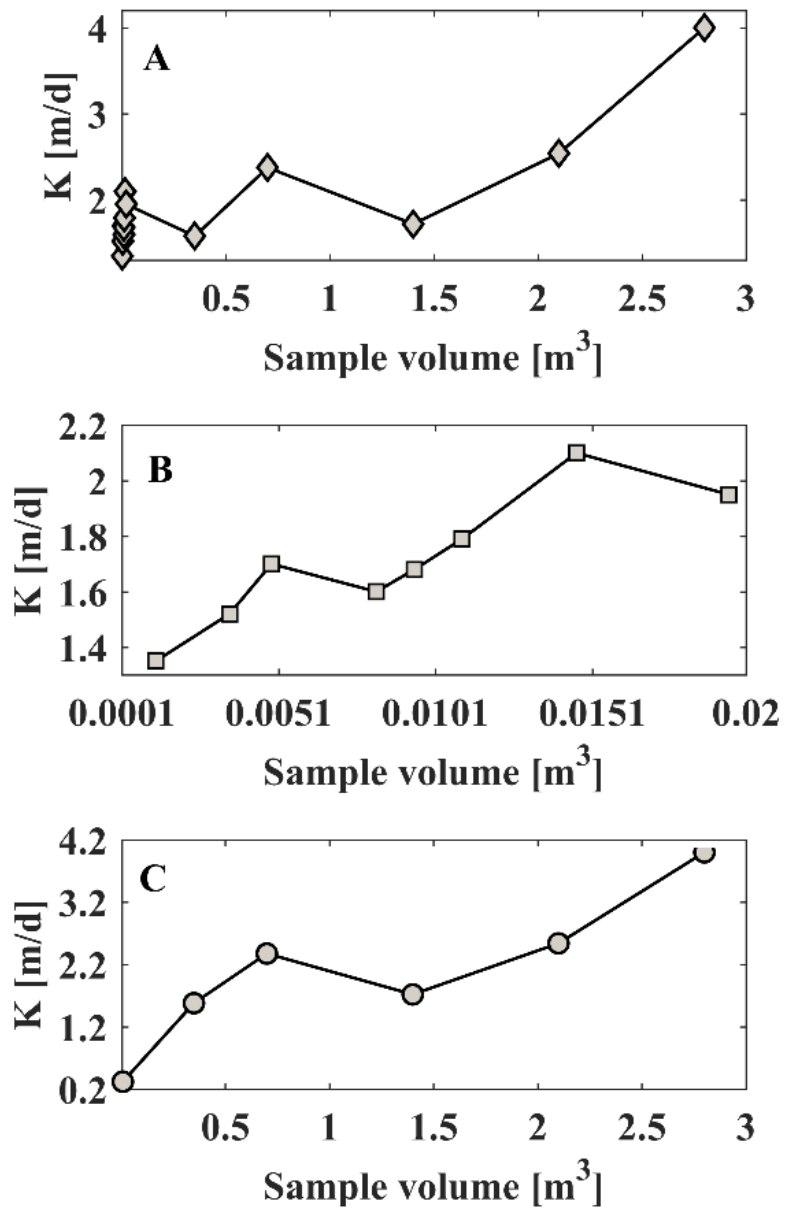
Figure 6

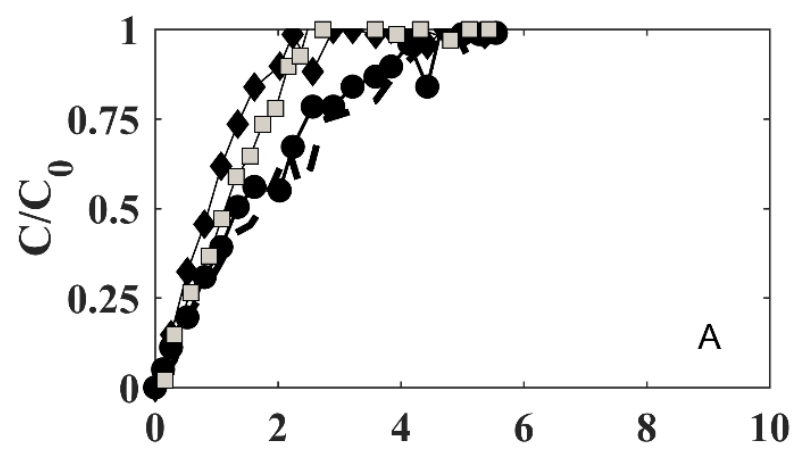

$$
\begin{array}{cc}
\longrightarrow & \mathrm{K}^{+} \text {(sample \#1) } \\
\longrightarrow & \mathrm{Cl}^{-} \text {(sample \#1) } \\
- & \mathrm{K}^{+} \text {(sample \#55) } \\
\longrightarrow & \mathrm{Cl}^{-} \text {(sample \#55) }
\end{array}
$$
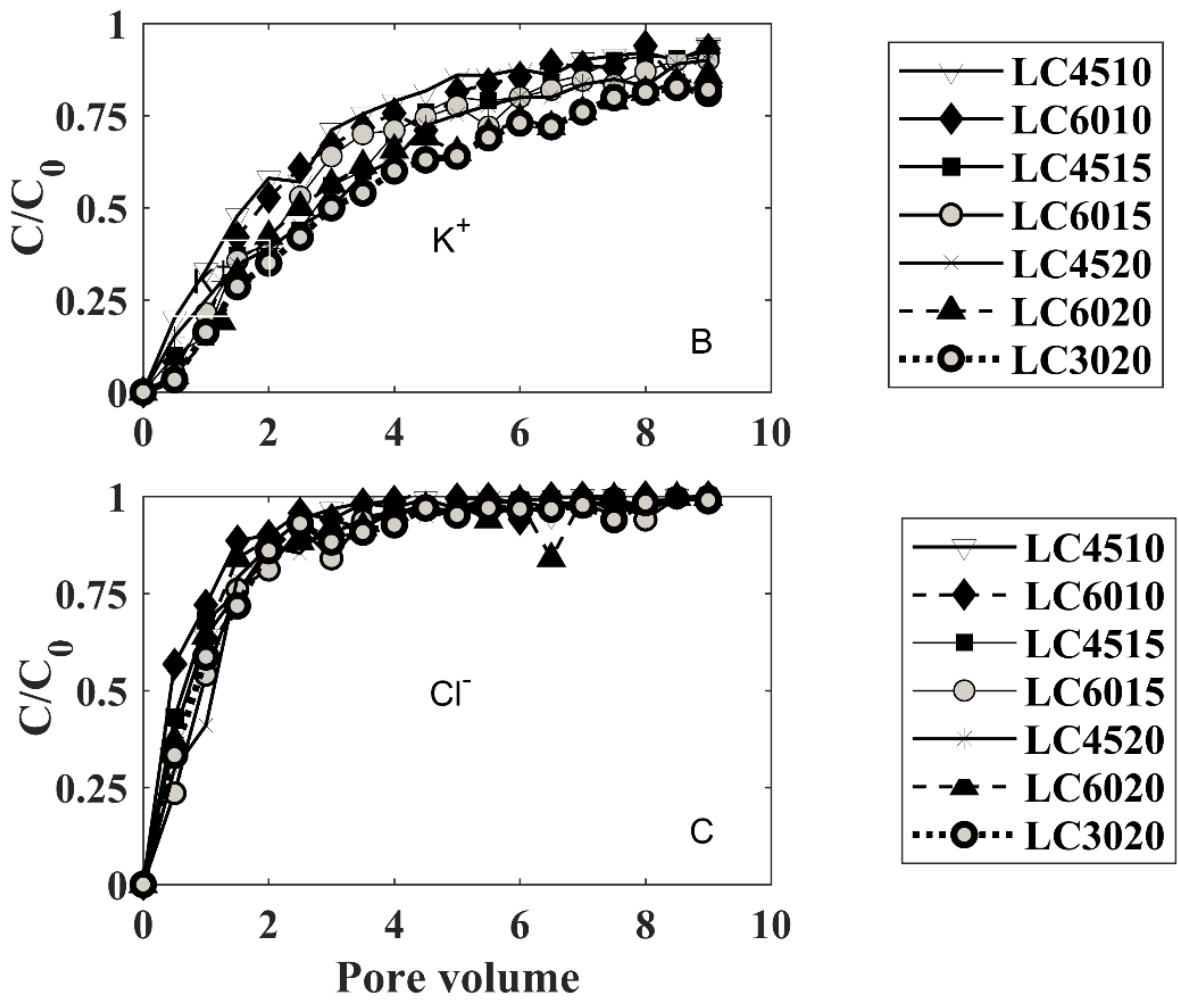
Figure 7
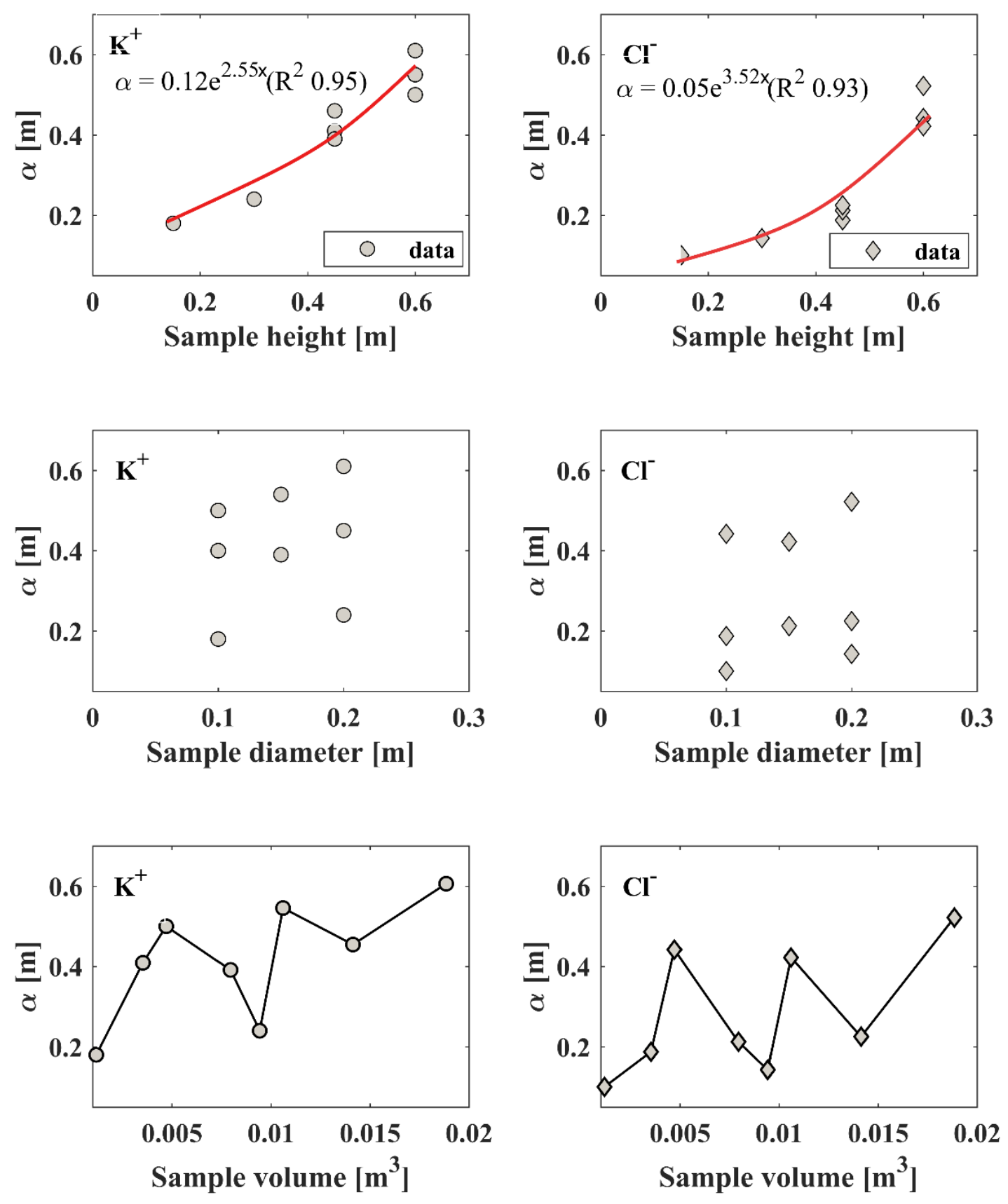
Figure 8
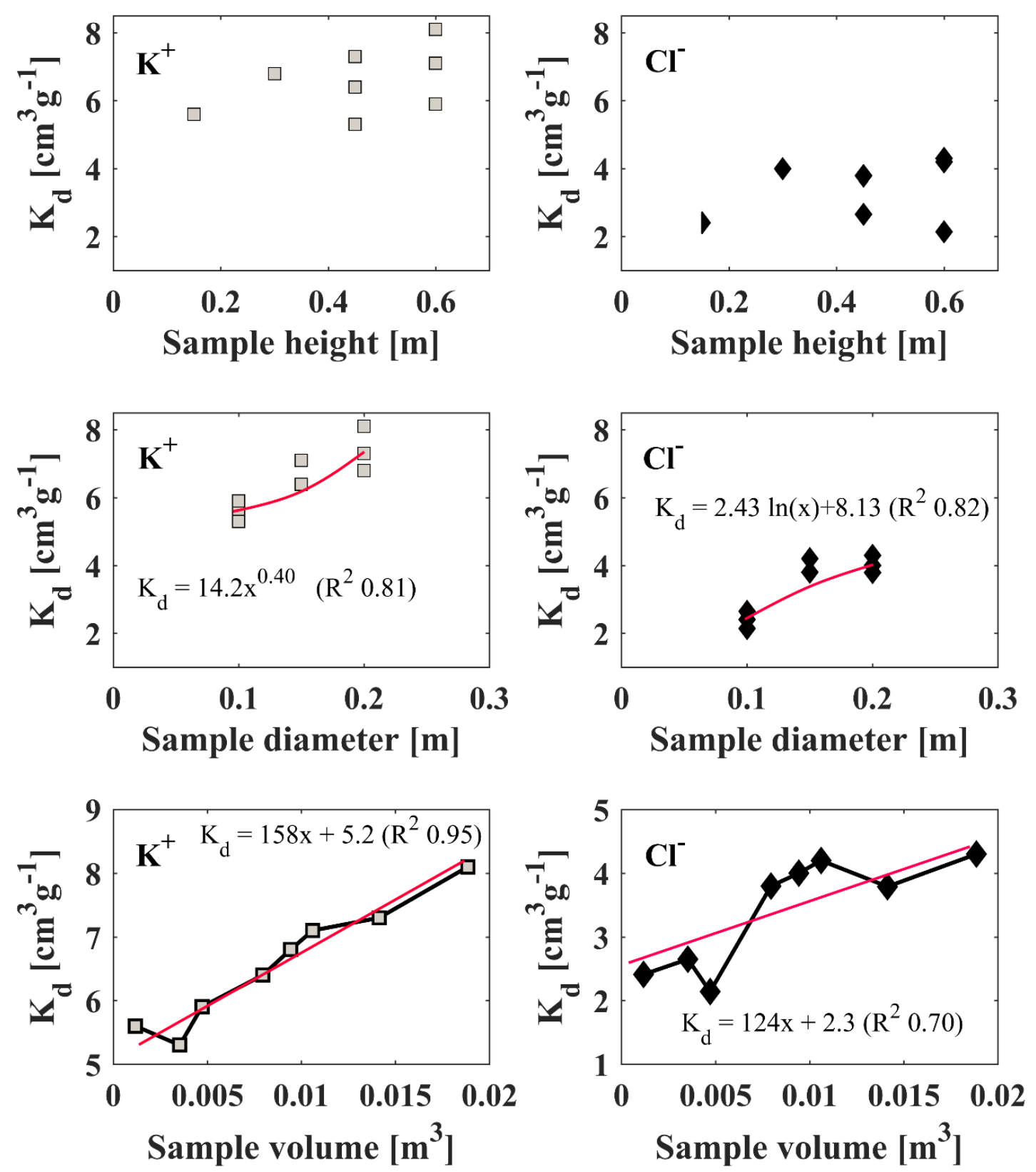


\section{List of Tables}

Table 1 Dimensions and number of undisturbed samples

Table 2 Summary of the soil physical characteristics of 55 small-scale undisturbed soil samples

Table 3 Basic statistics of $\mathrm{K}^{+}$and $\mathrm{Cl}^{-}$dispersivity and partition coefficient derived from the 55 small-scale miscible displacements tests

Table 4 Basic statistics of $\mathrm{K}^{+}$dispersivity and partition coefficient derived from the largescale miscible displacements tests

Table 5 Basic statistics of $\mathrm{Cl}^{-}$dispersivity and partition coefficient obtained for the largescale miscible displacements tests 
Table 1

\begin{tabular}{lcll}
\hline & $\begin{array}{l}\text { Number of } \\
\text { samples }\end{array}$ & Height $(\mathrm{m})$ & $\begin{array}{l}\text { Inner diameter } \\
(\mathrm{m})\end{array}$ \\
\cline { 1 - 4 } $\begin{array}{l}\text { Small-scale } \\
\text { sample }\end{array}$ & 55 & 0.15 & 0.10 \\
\cline { 1 - 3 } & 4 & 0.45 & 0.10 \\
Large-scale & 4 & 0.60 & 0.10 \\
sample & 4 & 0.45 & 0.15 \\
& 4 & 0.60 & 0.15 \\
& 4 & 0.45 & 0.20 \\
& 4 & 0.60 & 0.20 \\
& 1 & 0.30 & 0.20 \\
\hline
\end{tabular}


Table 2

\begin{tabular}{llllll}
\hline Property & Mean & SD & CV & Min & Max \\
\hline $\mathrm{n}[$ ] & 0.51 & 0.04 & 0.08 & 0.42 & 0.58 \\
$\mathrm{ne}[$ ] & 0.24 & 0.02 & 0.08 & 0.20 & 0.28 \\
$\rho_{\mathrm{d}}\left[\mathrm{g} \mathrm{cm}^{-3}\right.$ ] & 1.34 & 0.10 & 0.07 & 1.14 & 1.59 \\
$\mathrm{CEC}\left[\mathrm{cmol}_{\mathrm{c}} \mathrm{Kg}^{-1}\right]$ & 2.51 & 0.64 & 0.25 & 1.60 & 4.20 \\
sand (\%) & 56.20 & 3.24 & 0.06 & 48.50 & 61.50 \\
silt (\%) & 4.62 & 2.82 & 0.61 & 1.40 & 11.40 \\
clay (\%) & 39.18 & 3.51 & 0.09 & 32.50 & 46.10 \\
$\mathrm{Ma}[$ ] & 0.074 & 0.04 & 0.54 & 0.031 & 0.152 \\
$\mathrm{Mi}[]$ & 0.262 & 0.06 & 0.23 & 0.141 & 0.361 \\
Me [ ] & 0.172 & 0.05 & 0.29 & 0.099 & 0.263 \\
\hline
\end{tabular}

SD: standard deviation, CV: coefficient of variation, Min: minimum value, Max: maximum value, $\rho_{\mathrm{d}}$ : bulk density, $\mathrm{n}$ : total porosity, ne: effective porosity Ma: macroporosity, Me: mesoporosity, Mi: microporosity, CEC: cation exchange capacity. 
Table 3

\begin{tabular}{llllll}
\hline Property & Mean & SD & CV & Min & Max \\
\hline$\alpha[\mathrm{m}]$ for $\mathrm{K}^{+}$ & 0.18 & 0.19 & 1.05 & 0.003 & 1.50 \\
$\alpha[\mathrm{m}]$ for $\mathrm{Cl}^{-}$ & 0.10 & 0.08 & 0.75 & 0.002 & 0.34 \\
$\mathrm{~K}_{d}\left[\mathrm{~cm}^{3} \mathrm{~g}^{-1}\right]$ for $\mathrm{K}^{+}$ & 1.71 & 2.27 & 1.33 & 0.040 & 16.7 \\
$\mathrm{~K}_{d}\left[\mathrm{~cm}^{3} \mathrm{~g}^{-1}\right]$ for $\mathrm{Cl}^{-}$ & 0.55 & 0.51 & 0.91 & 0.002 & 1.64 \\
\hline
\end{tabular}

SD: standard deviation, CV: coefficient of variation, Min: minimum value, Max: maximum value 
Table 4

\begin{tabular}{lllllll}
\hline Sample & \multicolumn{2}{c}{ Mean } & \multicolumn{3}{c}{ Maximum } & \multicolumn{2}{c}{ Minimum } \\
\cline { 2 - 6 } Name & $\alpha[\mathrm{m}]$ & $\mathrm{K}_{\mathrm{d}}\left[\mathrm{cm}^{3} \mathrm{~g}^{-1}\right]$ & $\alpha[\mathrm{m}]$ & $\mathrm{K}_{\mathrm{d}}\left[\mathrm{cm}^{3} \mathrm{~g}^{-1}\right]$ & $\alpha[\mathrm{m}]$ & $\mathrm{K}_{\mathrm{d}}\left[\mathrm{cm}^{3} \mathrm{~g}^{-1}\right]$ \\
\hline LC4510 & 0.409 & 1.60 & 0.52 & 1.95 & 0.32 & 1.23 \\
LC6010 & 0.501 & 1.83 & 0.61 & 2.2 & 0.41 & 1.19 \\
LC4515 & 0.394 & 2.01 & 0.57 & 2.6 & 0.36 & 1.34 \\
LC6015 & 0.243 & 2.16 & 0.34 & 2.45 & 0.2 & 1.45 \\
LC4520 & 0.545 & 2.28 & 0.65 & 2.91 & 0.47 & 1.67 \\
LC6020 & 0.452 & 2.35 & 0.59 & 2.74 & 0.43 & 1.73 \\
LC3020 & 0.606 & 2.65 & 0.76 & 2.98 & 0.44 & 2.33 \\
\hline
\end{tabular}


Table 5

\begin{tabular}{|c|c|c|c|c|c|c|}
\hline \multirow{2}{*}{$\begin{array}{l}\text { Sample } \\
\text { Name }\end{array}$} & \multicolumn{2}{|c|}{ Mean } & \multicolumn{2}{|c|}{ Maximum } & \multicolumn{2}{|c|}{ Minimum } \\
\hline & $\alpha[\mathrm{m}]$ & $\mathrm{K}_{\mathrm{d}}\left[\mathrm{cm}^{3} \mathrm{~g}^{-1}\right]$ & $\alpha[\mathrm{m}]$ & $\mathrm{K}_{\mathrm{d}}\left[\mathrm{cm}^{3} \mathrm{~g}^{-1}\right]$ & $\alpha[\mathrm{m}]$ & $\mathrm{K}_{\mathrm{d}}\left[\mathrm{cm}^{3} \mathrm{~g}^{-1}\right]$ \\
\hline LC4510 & 0.187 & 0.99 & 0.25 & 1.2 & 0.15 & 0.89 \\
\hline LC6010 & 0.442 & 0.80 & 0.52 & 0.97 & 0.37 & 0.8 \\
\hline LC4515 & 0.212 & 1.42 & 0.29 & 1.5 & 0.16 & 1.15 \\
\hline LC6015 & 0.143 & 1.49 & 0.17 & 1.71 & 0.13 & 1.2 \\
\hline LC4520 & 0.422 & 1.57 & 0.47 & 1.94 & 0.27 & 1.05 \\
\hline LC6020 & 0.225 & 1.42 & 0.3 & 1.57 & 0.17 & 1.12 \\
\hline LC3020 & 0.522 & 1.60 & 0.65 & 1.77 & 0.39 & 1.43 \\
\hline
\end{tabular}

